\title{
COMPLEMENTARY AND CONFLICTING DISCOURSES OF LINGUISTIC DIVERSITY: IMPLICATIONS FOR LANGUAGE PLANNING
}

Sinfree Makoni, University of Penn State

Barbara Trudell, SIL International, Africa Area

Although the promotion of linguistic diversity is one of the main goals of language policy and planning in Africa, few attempts have been made to analyse how linguistic diversity has been construed in Africa within the different types of language planning discourses, and the implications of such discourses on language policy and planning. In this article we identify three main types of discourses of linguistic diversity: (i) linguistic diversity and the autonomy of language, (ii) linguistic diversity as problematic oddity, and (iii) linguistic diversity, identity and rights. In the article we demonstrate that these various discourses of linguistic diversity are both complementary and conflicting. We conclude the article by exploring the complexity of the relationships between these discourses as they affect language policy and planning.

\section{INTRODUCTION}

Beliefs about the nature of linguistic diversity are shaped by the discourses within which it is defined. Such beliefs are largely unexamined in popular use, and yet they are highly influential in a broad range of contexts, from national-level language planning to local decisions regarding education and language choice. It is thus important to understand the discursive sources of these beliefs, the perspectives to which each discourse is hospitable, and how the different discourses complement or contradict each other. These issues are the focus of this paper.

\section{THREE PERSPECTIVES}

The discourses regarding linguistic diversity in Africa can be grouped into three broad categories: those which view language as an autonomous phenomenon; those which see linguistic diversity in a negative light, either as exotic or politically unwelcome; and those which see linguistic diversity in terms of the political and cultural rights of the local communities which speak those languages.

\section{Linguistic diversity and the autonomy of language}

The propensity to regard language as autonomous has a long history in linguistics. With roots in positivistic paradigms of scientific inquiry, linguistics developed as the science of language 
(Yngve \& Wasik, 2004; Yngve, 1996). The focus of linguistic enquiry and description has tended to be on the nature of language itself; language data are seen as largely unrelated to humans except for being the necessary source of that data. The fundamental belief underpinning such linguistic description is the belief that languages are natural and not historically contingent, and that they are countable, discrete and bounded.

Mühlhaüsler (2004) describes this discourse as concerned with the enumerability of language. When languages are seen as discrete phenomena, they can be distinguished from each other and counted. Thus Adegbija lists over 450 languages in Nigeria (Adegbija 2004). The Ethnologue (Gordon 2005), arguably the most exhaustive catalogue of languages of the world, is also located in this discourse. In the arena of language policy, this discourse has influenced the emphasis on the number and proper selection of particular languages as a key feature of language policy (Makoni \& Pennycook, 2005). South Africa has eleven official languages, for example. Across Africa, many descriptions have been written of the unique phonological and grammatical features of African languages (see for example the Jounal of African Languages and Linguistics, the Journal of West African Languages and the South African Journal of African Languages); since many African languages are still neither written nor otherwise developed, descriptive linguistics continues to be popular.

Related to the notion of enumerability is that of 'language as object.' This is manifested in an argument that language has existence and value apart from its actual use in a society. Languages can thus be objectified, studied and counted with at most only a passing reference to their location within particular human cultures (Wurm, 1996). The objectification of language also encourages a view of communication as consisting of the transference of private messages from one code to another, the so-called 'conduit' metaphor (Reddy, 1979).

The notion of language as an autonomous object has recently come under sustained criticism from a number of different theoretical positions including Harris (1980, 1998), Yngve (1996, 2004a, 2004b), Reagan (2004), Makoni and Pennycook (2005, 2006). Canagarajh (2002) argues that one way out of this conceptual impasse is to include locally grounded views of language. Terms such as language shift and language loss (Fasold, 1990) have characteristically been used to describe sociolinguistic processes linguistically, without reference to the societal or political causes or impact of such processes. ${ }^{1}$ But not all locally grounded views of language can necessarily form the basis on which a viable applied linguistics project can be founded (Makoni \& Meinhof, 2007).

These aspects of autonomy discourse have been contested by scholars such as Djite (1988), who argues that the creation of artificial linguistic boundaries in West Africa has exaggerated the linguistic complexity of the region, making language planning problems more complex than they would be if actual communicative characteristics formed the basis of description of the linguistic situation.

\section{The ecology of language}

An important development within the discourse of linguistic autonomy has been the ecological approach to linguistic diversity (Nettle \& Romaine, 2000). In this paradigm languages are seen not as isolates, but as existing in a larger psychological and sociolinguistic environment. UNESCO describes this paradigm as treating language as an analogue to biodiversity, maintaining that 'just as there are hotspots of biodiversity, there are also hotspots of linguistic diversity'.2 Thus language ecology is the study of the interactions between a 
language and this larger environment (Haugen, 1972). Hornberger (2003) more specifically describes language ecology as encompassing processes of language evolution, language environment and language endangerment.

The biodiversity analogy has engendered the use of metaphors such as survival, and death (Crystal, 2000) and even more emotively, killer languages and linguistic genocide (SkutnabbKangas, 2000). This terminology highlights an ethical judgement that language loss is morally wrong, regardless of the particular conditions of its social uses, and that linguistic diversity is inherently good. This is a radical departure from the positivist approach to language change which has for so long been a hallmark of linguistic theory (see Reagan 2004 for a critique of such a position). We are using the term positivist to describe one of the overarching frameworks which are evoked in the 'language-as-object' discourse. Although the ecolinguistics approach has moved significantly away from that perspective, it nevertheless remains within the paradigm of 'language as bounded phenomenon' because it is derives from the notion of language as species.

The notion of language endangerment in particular has caught the popular imagination in the West and has fuelled the arguments of language rights advocates. Keebe (2003:47) describes this as a claim 'that the loss of a language is the permanent, irrevocable loss of a certain vision of the world, comparable to the loss of an animal or a plant'. Losing a language, irrespective of the number of speakers of that language, deprives humanity of a part of our universal human heritage insofar as the language embodies a unique worldview and knowledge of local ecosystems (Nettle \& Romaine, 2000:166).

Hill (2002), however, argues that the tendency to treat endangered languages as treasures in this way is 'hyperbolic valorization'. The 'treasure' which such languages represent is perhaps more highly valued by the linguist than by the local communities which speak them. This does not mean that noting and recording rare linguistic structures does not enrich linguists' knowledge of language, but Dorian (2002:137) urges linguists to look at rarity 'from a community-centered perspective rather than only from the perspective of global frequency of occurrence'.

Clearly, the ecological approach to linguistic diversity takes into account the sociolinguistic and political milieu of language development and language change, in a way which earlier linguistic paradigms have not. However, it is important to note that in this discourse language is still described as an autonomous phenomenon, and at times is itself accorded agency. This perspective may be seen in UNESCO's argument for language preservation:

The world's languages represent an extraordinary wealth of human creativity. They contain and express the total 'pool of ideas' nurtured over time through heritage, local traditions and customs communicated through local languages. ${ }^{3}$

The view of language as autonomous is the basis of most criticism of such approaches. Ecological paradigms, it is argued, fundamentally misrepresent the nature of language (and by implication linguistic diversity) because they treat language as if it were a natural, independently occurring phenomenon which is a vehicle of culture, rather than as a cultural artefact in itself. This inhibits opportunities to understand the role of human and political agency in language change and shifts in language ecology. Certainly, human existence is enriched through biological diversity, and the strongest ecosystems are characterised by diversity; but if languages are cultural artefacts rather than natural phenomena, then the 
ecological argument regarding the social good served by linguistic diversity is considerably weakened. It thus cannot be assumed that because biological diversity enriches human heritage, linguistic diversity necessarily has the same effect (Keebe, 2003; Pennycook, 2006).

Other, less contested assumptions about linguistic diversity which are made in the ecological approach include the individuality and equal value of all languages, including the weakened and endangered ones. This particular assumption derives from a belief in the value of all human cultures and individuals, no matter how vulnerable or disempowered. Elson (1987) articulates this view in his 'linguistic creed':

[A]ny language is capable of being a vehicle for complicated human interaction and complex thought, and can be the basis for a complex culture and civilization. Therefore, all languages deserve respect and careful study. ... Interest in and appreciation of a person's language is tantamount to interest in and appreciation of the person himself. All languages are worthy of preservation in written form by means of grammars, dictionaries, and written texts. This should be done as part of the heritage of the human race. ${ }^{4}$

The values expressed in this statement underlie much of the work currently carried out in the documentation and development of endangered languages. The value set on language in this context is directly related to its use by a unique people. The reference to language as a heritage of the human race also expresses the notion of the universal value of language. This notion informs the universalist approach to language rights which is discussed below.

The ecological discourse regarding linguistic diversity can have the effect of allowing 'language' to take the place of 'people', minimizing the essentially communicative and symbolic role of language within human society. Romaine (2004) acknowledges the problem:

In discussion of language maintenance, revitalization, etc. there is a tendency to reify languages, when it is communities ... we should be talking about. When we lose sight of people and the communities that sustain language, it becomes easy to argue as a number of critics have that there is no reason to preserve languages for their own sake.

Describing minority languages in terms of endangered biodiversity carries a further risk: it tends to exoticise the people who speak those languages or treat the speakers 'as if they were plants' (England, 2002:141). Clearly, protection of vulnerable languages must not encourage the marginalization of the speakers of those languages; the rhetoric of endangerment must not do disservice to the very people it is seeking to protect. As an indigenous person of South America once told one of the authors, 'we are not interested in being in a human zoo'. The voices of the communities whose languages are being threatened have to be given substantial attention.

\section{Linguistic diversity and language preservation}

In the arguments recounted above, language preservation is assumed to be a key strategy for maintaining linguistic diversity. However, the notion of language preservation is not in itself unproblematic. It tends to ignore the diversity within languages in favour of one form. The fact that standardization and corpus planning are generally carried out under the aegis of nonnative speakers of the languages adds further to the possibility that the written form of a 
language may not be perceived by its speakers as belonging to them in the way the oral forms of the language do.

This prompts another observation. Notions of linguistic autonomy and ecolinguistics have their roots in Western philosophical traditions and current Western values. Although that fact does not negate their utility, it does raise the question of whether African correlates to these discourses exist, and, given a concern with diversity, what their implications might be. The following African examples, suggest some of the issues.

One interesting case in which ecological concerns and cultural concerns have been combined is the celebrated environmental work of Dr Wangari Maathai, a Kenyan activist and Nobel Peace Prize winner. Dr Maathai has clearly linked preservation of the natural environment with the vitality of Kenyan cultures. ${ }^{5}$ It is notable, however, that her articulation of this link does not extend specifically to the preservation of local languages, some of which are significantly under threat. The same attitude may be seen in a variety of disciplines in which environmental discourses are used ${ }^{6}$ but rarely in connection with language preservation.

In other cases, however, the need for language development and cultural preservation are clear to threatened ethnic communities. Abundant anecdotal evidence from the ethnic communities of southern Sudan indicates that as these communities have been faced with what they perceived as ethnocide at the hands of the northern Sudanese government, their interest in committing the details of their culture and languages to writing has soared (Gilley, 1999). This vivid perception of language endangerment on the part of the speakers themselves led to active participation in local language planning and development activities. It appears that a people's perception of the importance of their linguistic (and cultural) distinctives is enhanced when they find themselves in such a climate of extreme hostility to their ethnic and cultural identity.

Still, it appears that the notions of linguistic autonomy and ecolinguistics strike few familiar chords among African language communities. For African scholars, the concern with linguistic diversity tends to centre far more on issues of multilingualism and political inclusion (Roy-Campbell \& Qorro, 1997; Muthwii \& Kioko, 2004; Adejunmobi, 2004). An exception to this is the recent work by Batibo (2005), in which the author makes an impassioned case for the need to 'deal with the problem of language shift and death among the minority languages' (p.vii).

In another case, in South Africa the notions of language shift and language death have been used in a vigorous debate on Afrikaans at the University of Stellenbosch, even though there is no overwhelming evidence of large-scale language decline in the immediate community. The University reports that $70 \%$ of its students and $65 \%$ of its teaching staff speak Afrikaans. Such use of notions of language death and language preservation should be interpreted not as pointing to language death or massive language shift, but as a strategy to pre-empt decline or create opportunities for an expanded use of Afrikaans as the 'language of tuition' (www.su.ac.za).

\section{Language diversity as a problematic oddity}

The discourse set which sees linguistic diversity as both exotic and problematic arguably has its genesis in the colonial domination of Africa. The supposedly 'exotic' nature of African languages, along with their associated cultures, was a theme of colonial European 
sociopolitical discourse. Linguistic features such as tone, length, and clicks, not found in European languages, contributed to the perception, as did the rich range of language varieties found in many parts of the continent (See, for example, Migeod, 1925). To the Europeans, this made them of curious academic interest. The post-colonial pendulum swing takes fundamentally the same view of language in asserting the opposite: linguistic diversity as a resource.

The evidence of abundant linguistic diversity led merchants, colonial officers and missions authorities in the British colonies to conclude that English was a preferable alternative to local languages for the administrative, communicative and educational tasks they had set themselves in Africa (Migeod, 1925:21). An English-based Pidgin developed in the British colonial holdings in West Africa (Vernon-Jackson, 1967), affirming the belief that any variety of English was preferable to attempting to communicate in the plethora of African languages in use by the colonised populations.

The swift takeover of European-style education - in European languages - in African communities over the first decades of the colonial era confirmed the marginalised place of African languages and cultures in the new world order. Further marginalization of African languages in 'modern' Africa came with the introduction of so-called adapted education in the British colonies (King, 1971). This attempt at education reform, originating in the United States and Britain, advocated a curriculum embedded in local knowledge and local languages (Wolf, 2001). The vigorous rejection of adapted education by African parents, who suspected it as an attempt to keep them from acquiring European knowledge and power (Ball, 1983), included rejection of both the local knowledge curriculum and the local language in which it was to be taught. This sense of the inappropriateness of African language as a medium of conveying knowledge in the formal classroom continues to be a widespread perception among African parents.

As independence swept across the African continent in the second half of the 20th century, the influence of the discourse of linguistic diversity as both exotic and anachronistic continued. The economic and political agenda of African states' new Western partners continued to favour the primacy of non-African languages and cultures in the continent's sociocultural development. At the Conference of African States on the Development of Education in Africa (1961), ministers of the newly independent African nations presented their hopes for a uniquely African education which would include serious attention to cultural and linguistic diversity. In response, their Western partners at the conference emphasised the need to refashion African education to match their own vision for economic development $-\mathrm{a}$ vision which revolved around global realities, not African ones. In the end, recognition of cultural and linguistic diversity failed to appear on the international agenda for the development of African education.

Antagonism to linguistic diversity has been further exacerbated by the advent of the nationstate in Africa. Formal recognition of multiple languages - and language communities - was, and is, seen as a significant barrier to national integration (Blommaert, 2006). Bamgbose (1991:14) describes the two facets of this argument: the notion that multilingualism inhibits national integration, and the notion that national integration necessarily involves the emergence of a nation state with only one national language. Bamgbose points out that in fact, the most serious challenges to national integration come from quite other sources than language; nevertheless, the notion that linguistic diversity is a threat to national unity has persisted. 
So it has been that post-colonial governments have maintained and even extended the position of European languages in national education and political systems. Adegbija (1994:33-4) analyzes the post-colonial place of European languages in this way:

Post-colonial policy makers in Africa have largely rubber-stamped or toed the line of language and educational policies bequeathed to them by the colonial masters. . . . Educational systems, which have widened and extended beyond what they were in colonial days, have been further used to entrench and perpetuate the feeling of the inviolable worth of colonial languages.

In this environment, linguistic diversity becomes a characteristic to ignore as far as possible. However, in recent decades challenges have emerged to the entrenched notion that linguistic diversity is troublesome and anachronistic. Spearheaded by international institutions such as UNESCO, there have been powerful moves to popularise the idea that linguistic diversity deserves to be addressed in political and educational spheres. As a result, African government language policies tend to be increasingly positive towards acknowledgement of the languages within their borders. In particular, the larger African languages are receiving some degree of official recognition: examples in eastern Africa include Setswana in Botswana (NyatiRamahobo, 2004), Chichewa in Malawi (Kayambazinthu, 2004), and most notably, KiSwahili in Tanzania (Roy-Campbell \& Qorro, 1997). However, the support for linguistic diversity found in national language policy statements or in the emphasis on it as a resource is seldom played out in the actual provision of means for implementation of such policies.

Is the discourse of linguistic diversity as exotic and problematic any less foreign to Africa than the discourse of linguistic autonomy and ecology of language discussed above? Certainly, both originated with colonial Western views of African languages and cultures. Their embedding in post-colonial national policies can be traced to the nature of the political structures brought about by colonial domination of the continent. However, after so many decades of neglectful or negative policy regarding linguistic diversity by African governments, it is difficult to maintain that the discourse in which linguistic diversity is conceived as problematic is essentially foreign to Africa any more.

\section{Linguistic diversity, identity and rights}

A third discourse set regarding linguistic diversity focuses on the maintenance of language as an aspect of cultural identity, political enfranchisement and human rights.

The discourse of language and identity is grounded in the belief that language and culture are profoundly entwined. Whether language actually predisposes its speakers to see the world in a certain way (Sapir, 1929:207), or whether language is itself a reflection of culture, the role of language in mediating and defining social relations is considered within this discourse to be crucial (Kramsch, 1998:77). This is not to say that the nature of the language-culture connection is static; but May (2001) argues that language is nevertheless a significant feature of ethnic identity:

To say that language is not an inevitable feature of identity is not the same as saying it is unimportant ... Language cannot be relegated, as some commentators would have it, to a mere secondary or surface characteristic of ethnicity (May 2001:129). 
In sub-Saharan Africa, certainly, language functions as one of the most obvious markers of culture. Webb and Kembo-Sure (2000:122) note that in Africa, 'people are often identified culturally primarily (and even solely) on the basis of the language they speak'. Describing the role of language in traditional Zambian societies particularly, Serpell (1993:97) notes that the Zambian languages are

intimately bound up with many of the society's traditional practices, and enshrine in multiplex and subtle ways the epistemological foundations of indigenous moral values.

Hence in this discourse linguistic diversity becomes symbolic of cultural diversity, and the maintenance or revitalization of language signals ongoing or renewed validity of the culture associated with that language. For speakers of Africa's true minority languages - those which are unwritten and largely unacknowledged - this is a powerful argument for language development and the preservation of linguistic diversity.

A related discourse links language use and language choice to issues of power imbalance. It is undeniably true that communities of speakers of smaller languages tend also to be the less politically empowered communities. Indeed, May (2000) contends that

Language loss is not only, perhaps not even primarily, a linguistic issue - it has much more to do with power, prejudice, (unequal) competition and, in many cases, overt discrimination and subordination. . . . Language death seldom occurs in communities of wealth and privilege, but rather to the dispossessed and disempowered. (p.368)

Romaine (2004) also describes the power imbalances underlying the material, political and economic domination of 'most of the world's small language communities'. And, in his study of the motivations underlying language planning and policy, Ager, 2001: 158) notes that

because of their majority or minority status, many communities within the state are vociferous in support of their own identity and desire to ensure that their language, customs and traditions are not lost. . . . Language is an almost inevitable point of contention between communities.

This discourse of language-related power imbalances could be seen as contradicting Bamgbose's contention (cited above) that linguistic diversity is not an inherent threat to national unity. However, both of these arguments are linked by the crucial point that linguistic diversity per se is not a political problem: rather, ignoring linguistic diversity is the problem. Distinct language practices are often a feature of communities that are marginalised from access to resources and power, but national unity need not imply cultural or linguistic uniformity. Indeed, as national authorities recognise the right of individual communities to distinct language and cultural practices, and do not withhold resources or power from such communities, the resulting unity is likely to be stronger and more representative. Those most concerned with national unity must ask themselves whether their goal is not unity, but rather a particular configuration of national power structures. 


\section{Linguistic human rights}

In a further move along the continuum of language and politics, the discourse which relates language issues to the political and cultural rights of communities gives rise to a more militant approach to linguistic diversity which focuses on the dominance and perceived imperialism of large, prestigious world languages - primarily English (Phillipson, 1992) - over the smaller languages of the world. The notion of linguistic human rights arises within this discourse. Freedom to use one's own language is seen as a human right, and language diversity becomes symbolic of the defence of this universal human right. This discourse may at times use the terminology of language ecology to describe endangered and disempowered language communities (Skutnabb-Kangas, 2000), but its basis is not actually that of biodiversity or of language as a natural phenomenon needing protection from endangerment. Rather, a legal and political framework underlies the discourse of language rights (Universal Declaration of Linguistic Rights, 1998)

In the following section we describe the nature of the African political context within which rights regimes have become increasingly salient, and then analyse the nature of the rights discourses, focusing on what they reveal about the nature and conceptualizations of languages and language diversity within Africa.

The rights regimes became increasingly prominent in the 1990s, a period characterised by the appearance of democratic movements and multiparty elections in Africa. The main proponents of human rights in Africa have been non-governmental organizations and professional associations of teachers and lawyers. The African state has also contributed towards the consolidation of human rights regimes through a series of human rights protocols, even though there is increasing awareness of the potentially limited role which rights regimes have to effect social, political and economic equality. In addition, the interest and commitment to human rights regimes by African states can be seen at a pan-African level. A number of important pan-African structures have been set up to implement and protect human rights regimes, including (i) the Pan-African Parliament, (ii) the African Court of Justice (iii) the Economic, Social and Cultural Council, (iv) the Peace and Security Council, and (v) the African Commission on Human Rights and People's rights.

Yet in spite of the high profile of the rights discourses in Africa and the apparent commitment of African states to enforce and protect different types of rights, the situation is complicated by the African state's general proclivity to compromise rights ostensibly for the purposes of maintaining political and military security. The relationship between rights and security is further complicated by the abiding controversy in African scholarship on the nature of rights as a construct (Bhebhe \& Ranger, 2001; Zeleza, 2004). Those who make a universalist argument insist that every individual has inalienable rights, and that these rights are not contingent upon a specific historical context. Those who maintain a relativist position, on the other hand, argue that a unique set of rights and discourses has developed in Africa as a product of its unique historical context. These rights are expressed and articulated in a paradigm which places a premium on human dignity more than rights. Language diversity is not a defining characteristic of this type of rights discourse.

However, the discourse of linguistic human rights does draw from this larger rights discourse. Ogechi (2003: 280) identifies the United Nations Universal Declaration of Human Rights, promulgated in 1948, as a primary pillar of language rights: 
Everyone is entitled to all the rights and freedoms set forth in this Declaration (of human rights) without distinction of any kind, such as race, colour, sex, language, religion, political or other opinion, national or social origin, property, birth or other status. ${ }^{8}$

Ogechi further notes that language rights are integral to numerous subsequent UN documents. Musau (2004:59) describes a broad range of linguistic human rights, 'aimed at the promotion of linguistic justice and the removal or prevention of linguistic inequalities or injustices that may occur because of language'. Musau and Ogechi do not entirely agree in their analyses of the status of linguistic rights in their country of focus - Kenya - but both are clearly situated in the rights discourse regarding linguistic diversity.

However, the notion of linguistic human rights has been subjected to considerable criticism (Stroud, 2000; Makoni \& Pennycook, 2005, 2006). This criticism coalesces around a deepseated scepticism regarding the definition of language that underpins this discourse, itself related to scepticism regarding western notions of language in non-western contexts. This perspective can be understood as part of a broader critique of linguistics and some of its notions of language (see Harris, 1981; Yngve 1996; Yngve \& Wasik 2004; Makoni \& Pennycook 2006).

For other scholars such as Ngugi wa Thiong'o and Mazisi Kunene, however, it is only through a renewed focus on the use of indigenous languages in language rights discourse that rights may be protected and enhanced. These scholars see contemporary discourses of rights as deeply entrenched in, and shaped by, European linguistic constructs. Rights discourses that are entrenched in European idiom will not have the desired effect when the people who are meant to be affected have limited knowledge of European languages (Mazrui 2004).

Not only so, but the profound connection evident between language and culture means that the protection of linguistic diversity among African populations is more difficult to maintain when languages are characterised as autonomous rather than as culturally constructed. The tendency to assign agency to language is still reflected in the Asmara Declaration of African Languages of January 17, 2000: article 1 states that 'African languages must take on the duty, the responsibility, and the challenges of speaking for the continent'. This approach carries all the limitations of the autonomous approach to language described above.

In the light of this complex situation, it is important to ask to what extent the discourse of identity, culture and rights resonates among African citizens and decision makers? The identification of specific languages with specific cultures varies across the continent, depending in part on the role that the various languages play in these largely multilingual cultures. Certainly for the $66 \%$ of African citizens who live in rural areas ${ }^{9}$ (and so are unlikely to be fluent in international languages), the mother language is closely identified with their way of life. The desire to preserve and develop their languages is not uncommon among communities which speak small minority languages, as one author (Trudell) has experienced in African countries as diverse as Kenya, DR Congo, Ghana, Senegal, Cameroon, Benin and Sudan.

The rights discourse clearly has a strong recent history on the African continent. Whether language is widely considered to be a human right is debatable, however; scholarly attention to compliance with linguistic human rights by African nations does not seem to be matched by a more general sense of the place of language in human rights discourse. 


\section{CONCLUSION}

In examining the array of discourses of linguistic diversity which influence beliefs and policy in sub-Saharan Africa, a few conclusions seem clear. One is that Africans tend to value multilingualism highly (Simire 2004; Roy-Campbell and Qorro 1997). This deep-seated and generalised value is highly pragmatic, with few obvious theoretical roots in discourses of ecology or rights. However, the fact that it is so widespread lends support to positive discourses of linguistic diversity on the continent.

Another conclusion is that the pressure of a largely monolingual movement towards global culture is maintaining English - and to a lesser extent French - in a place of dominance in the minds of many Africans. Formal schooling, higher education, the Internet and modern telecommunications all increase the value of fluency in English. This fact, although not inherently inimical to multilingualism or the maintenance of African languages, does provide fuel to those discourses which denigrate African languages.

These colliding values account for the tension that exists between the various discourses of linguistic diversity as they are found in sub-Saharan African societies. Constructive resolution of this tension is only possible as the value of multilingualism, including fluency in European languages, is broadened to allow space for the continued development of minority languages for education and communication.

A related tension also characterises discussion of linguistic diversity in Africa: the tension between regarding language as simply a means of communication and regarding language as a profound marker of cultural identity. Discourse choices which downplay the self-identity role of language by denying its bounded nature entirely are not adequate models of linguistic diversity for Africa. Equally, those discourses which ignore the contingency of language on social and communicative choices are incomplete models. The discourse of 'language as communicative tool' must be balanced where needed by the discourse of 'language as cultural marker' if the benefits of both are to be attained by the millions of Africans who live the reality of linguistic diversity.

\section{ENDNOTES}

${ }^{1}$ One notable exception to this rule is the linguistics text African Voices (Webb and Kembo-Sure 1999). Intended primarily as an introductory linguistics text, this treatment of linguistics is heavily seeded with sociopolitical commentary on linguistic processes as played out in African societies.

${ }^{2}$ Http://portal.unesco.org/education/en/ev.php

${ }^{3} \mathrm{http}: / /$ portal.unesco.org/education/en/ev.php

${ }^{4} \mathrm{Http} / / /$ www.sil.org/sil/linguistic_creed.htm. Accessed 10 January 2006.

${ }^{5} \mathrm{http}: / / \mathrm{www}$.gbmna.org.

${ }^{6}$ See the Special Issue of the Journal of Southern African Studies, 26.4 (2000).

${ }^{8}$ United Nations Universal Declaration of Human Rights, as quoted in Ogechi 2003.

9 Population Reference Bureau, <http://www.prb.org>. The definition of 'rural' used in this database of population statistics is a community environment of less than 2000 persons. 


\section{REFERENCES}

ADEGBIJA, E. 2004. Multilingualism: A Nigerian case study. Lawrencevill, NJ: Africa World/Red Sea.

1994 Language attitudes in Sub-Saharan Africa: A sociolinguistic overview. Clevedon: Multilingual Matters Ltd.

ADEJUNMOBI, M. 2004. Vernacular palaver. Clevedon: Multilingual Matters Ltd.

AGER, D 2001. Motivation in language planning and language policy. Clevedon: Multilingual Matters Ltd.

BALDAUF, RB, JR. AND RB KAPLAN. (EDS). 2004. Language planning and policy in Africa, Volume 1: Botswana, Malawi, Mozambique and South Africa. Clevedon: Multilingual Matters Ltd.

BALL, STEPHEN J. 1983. Imperialism, social control and the colonial curriculum in Africa. Journal of Curriculum Studies, 15(3): 237-263.

BAMGBOSE, AYO. 1991. Language and the nation: The language question in Sub Saharan Africa. Edinburgh: Edinburgh University Press.

BATIBO, HERMAN. 2005. Language decline and death in Africa: Causes, consequences and challenges. Clevedon: Multilingual Matters Ltd.

BHEBHE, N \& T RANGER. 2001. The historical dimensions of democracy and human rights in Zimbabwe: Precolonial and colonial legacies. Harare: University of Zimbabwe Press.

BLOMMAERT, JAN. 2006. Language policy and national identity. In Ricento, T (ed.), An introduction to language policy: Theory and method. Oxford: Blackwell Publishing. $\mathrm{x}-\mathrm{xii}$.

CANAGARAJAH, AS. 2002. Celebrating local knowledge on language education. Journal of Language, Identity and Education, 1 (4):243-261

CONFERENCE OF AFRICAN STATES ON THE DEVELOPMENT OF EDUCATION IN AFRICA, ADDIS ABABA. 1961. Final Report. UNESCO.

CRYSTAL, DAVID. 2000. Language death. Cambridge: Cambridge University Press.

DJITE, PAULIN. 1988. Correcting errors in language classification:monolingual nuclei and multilingual satellites. Language problems and language planning, 12(1):1-14.

DORIAN, NANCY. 2002. Commentary: broadening the rhetorical and descriptive horizons in endangered-language linguistics. Journal of Linguistic Anthropology, 12(2): 134140. 
ENGLAND, N. 2002. Commentary: Further rhetorical concerns. Journal of Linguistic Anthropology, 12(2): 141-143.

FASOLD, R. 1990. The sociolinguistics of language. Oxford: Blackwell.

GILLEY, LEOMA 1999. Facilitating orthography development with mother-tongue speakers. Notes on Linguistics, 2(4): 185-192.

GORDON, RAYMOND (ED.). 2005. Ethnologue. 15th ed. Dallas: SIL International.

HARRIS, R. 1980. The language-makers. Ithaca, NY: Cornell University Press.

HARRIS, R. 1981. The language myth. London: Duckworth.

HARRIS, R. 1998. Introduction to integrational linguistics. London: Pergamon.

HAUGEN, E. 1972. Linguistic Ecology. Stanford: Stanford University Press.

HILL, J. 2002. 'Expert rhetorics' in advocacy for endangered languages: Who is listening, and what do they hear? Journal of Linguistic Anthropology, 12(2):119-133.

HORNBERGER, N. 2003. Multilingual language policies and the continua of biliteracy: An ecological approach. In Hornberger, $\mathrm{N}$ (ed.), Continua of biliteracy: An ecological framework for educational policy, research and practice in multilingual settings. Clevedon: Multilingual Matters Ltd.

HUDSON, RA. 1995. Invitation to Linguistics. Oxford: Blackwell.

KAYAMBAZINTHU, E. 2004. The language planning situation in Malawi. In Baldauf and RB Kaplan (eds), Language planning and policy in Africa, Volume 1: Botswana, Malawi, Mozambique and South Africa. Clevedon: Multilingual Matters Ltd. 53-118.

KEEBE, D. 2003. Language policy and linguistic theory. In J Marais and M Morris (eds), Languages in a globalising world. Cambridge: Cambridge University Press. 47-58.

KING, K. 1971 Pan-Africanism and education: A study of race, philanthropy and education in the Southern States of America and East Africa. Oxford: Clarendon Press.

KRAMSCH, C. 1998. Language and culture. Oxford: Oxford University Press.

MAKONI, S \& A PENNYCOOK. 2005. Disinventing and reconstituting language. International Journal of Critical Language Studies, 2(3):137-156.

MAKONI S \& A PENNYCOOK (eds). 2006. Disinventing and reconstituting languages. Clevedon: Multilingual Matters.

MESTHRIE, R, J SWANN, A DEUMERT \& W LEAP. 2000. Introducing Sociolinguistics. Philadelphia: John Benjamins. 
MAY, S. 2001. Language and minority rights: Ethnicity, nationalism and the politics of language. Essex: Pearson Education Ltd.

2000. Uncommon languages: The challenges and possibilities of minority language rights. Journal of Multilingual and Multicultural Development, 21(5): 366-385.

MIGEOD, F. 1925. Through British Cameroons. London: Heath Cranton.

MUSAU, P. 2004. Linguistic human rights in Africa: Challenges and prospects for indigenous languages in Kenya. In Muthwii, MJ \& AN Kioko (eds), New language bearings in Africa: A fresh quest. Clevedon: Multilingual Matters Ltd. 155-165.

MUTHWII, MJ \& AN KIOKO (EDS). 2004. New language bearings in Africa: A fresh quest. Clevedon: Multilingual Matters Ltd.

NETTLE, D \& S ROMAINE. 2000. Vanishing voices. Oxford: Oxford University Press.

NYATI-RAMAHOBO, L. 2004. The language situation in Botswana. In Baldauf, RB Jnr \& RB Kaplan, Language planning and policy in Africa, Volume 1: Botswana, Malawi, Mozambique and South Africa. Clevedon: Multilingual Matters Ltd.

OGECHI, NO. 2003. On language rights in Kenya. Nordic Journal of African Studies, 12(3): 277-295.

PHILLIPSON, R.1992. Linguistic imperialism. Oxford: Oxford University Press.

REAGAN, T. 2004. Objectification, positivism and language studies: A reconsideration. Critical Inquiry in Language Studies: An International Journal, 1: 47-60.

REDDY, MT. 1979. The conduit metaphor: A case of frame conflict in our language about language. In Ortony, A (ed.), Metaphor and thought. Cambridge: Cambridge University Press. 164-201.

ROMAINE, S. 2004 Linguistic diversity, sustainable development, and the future of the past. Paper given at the Linguapax 2004 Conference on Linguistic Diversity, Sustainability and Peace, Barcelona, 2004.

ROY-CAMPBELL, Z \& MAS QORRO. 1997 Language crisis in Tanziania: The Myth of English vs. Education. Dar es Salaam: Mkuki Na Nyota Publishers.

SAPIR, E. 1929 The status of linguistics as a science. Language, 5: 207-214.

SERPELL, R. 1993 The significance of schooling. Cambridge: Cambridge University Press.

SIMIRE, GO. 2004. Developing and promoting multilingualism in public life and society in Nigeria. In Muthwii, MJ \& AN Kioko (eds), New Language Bearings in Africa: A Fresh Quest. Clevedon: Multilingual Matters Ltd.231-244.

SKUTNABB-KANGAS, T. 2000 Linguistic genocide in education - or worldwide diversity and human rights? Mahwah, NJ: Lawrence Erlbaum. 
STROUD, C. 2000 Language and democracy: The notion of linguistic citizenship and mother tongue. In Legère, $\mathrm{K} \& \mathrm{~S}$ Fitchat (eds), Talking Freedom: language and democratization in the SADC region. Windhoek: Gamsberg: Macmillan.67-74.

1998 Universal Declaration of Linguistic Rights. Barcelona: Universal Declaration of Linguistic Rights Follow-up Committee.

VERNON-JACKSON, HOH. 1967. Language, schools and government in Cameroon. NY: Columbia University Teacher's College Press.

WEBB, V \& KEMBO-SURE (EDS). 2000. African voices. Oxford: Oxford University Press.

WOLF, HG. 2001 English in Cameroon. Berlin: Mouton de Gruyter.

WURM, SA. 1996. Atlas of the world's languages in danger of disappearing. Paris: UNESCO.

YNGVE, V 1996. From grammar to science: New foundations for General Linguistics. Amsterdam/Philadelphia. John Benjamins.

YNGVE, V. 2004a. Issue in Hard Science Linguistics. In Yngve, V \& Z Wasik (eds) HardScience Linguistics. New York: Continuum.14-27.

YNGVE, V. 2004b. An introduction to Hard-Science Linguistics. In Yngve, V \& Z Wasik (eds) Hard-Science Linguistics. New York: Continuum. 27-35.

YNGVE, V AND Z WASIK. 2004. Hard-science Linguistics. London \& New York: Continuum.

ZELEZA, P. 2004. Human rights and development in Africa: New contexts, challenges and opportunities. Paper presented at the International Conference on the African Commission on Human and People's Rights, Uppsala, Sweden.

\section{BIOGRAPHIC NOTE}

Sinfree Makoni has published extensively in Applied Linguistics. His special areas of interest are language and health, language and aging and language use in urban African environments.

sbm12@psu.edu

Barbara Trudell, who works for SIL International, has done extensive work in building capacity of leaders in minority languages in Peru and sub-Saharan Africa. Email: barbara_trudell@sil.org 